\title{
Effects of feeding grass or red clover silage cut at two maturity stages in dairy cows. 1. Nitrogen metabolism and supply of amino acids
}

\author{
A. Vanhatalo, ${ }^{* 1}$ K. Kuoppala, $†$ S. Ahvenjärvi, $†$ and M. Rinne $†$ \\ *Department of Animal Science, University of Helsinki, PO Box 28, Fl-00014 Helsinki, Finland \\ †MTT Agrifood Research Finland, Animal Production Research, FI-31600 Jokioinen, Finland
}

\begin{abstract}
This study investigated the effects of plant species (red clover vs. timothy-meadow fescue) and forage maturity at primary harvest (early vs. late cut silage) on rumen fermentation, nutrient digestion, and nitrogen metabolism including omasal canal AA flow and plasma AA concentration in lactating cows. Five dairy cows equipped with rumen cannulas were used in a study designed as a $5 \times 5$ Latin square with 21 -d periods. The diets consisted of early-cut and late-cut grass and red clover silage, respectively, and a mixture of late-cut grass and early-cut red clover silages given ad libitum with 9 $\mathrm{kg} / \mathrm{d}$ of a standard concentrate. Grass silage dry matter intake tended to decrease but that of red clover silages tended to increase with advancing maturity. Milk yields were unchanged among treatments, milk protein and fat concentrations being lower for red clover than for grass silage diets. Rumen fluid $\mathrm{pH}$ was unchanged but volatile fatty acid and ammonia concentrations were higher for red clover than for grass silage diets. Intake of $\mathrm{N}$, and omasal canal flows of total nonammonia $\mathrm{N}$ (NAN), microbial NAN, and dietary NAN were higher for red clover than for grass silage diets but were not affected by forage maturity. However, microbial NAN flow and amount of $\mathrm{N}$ excreted in the feces decreased with advancing maturity for grass diets but increased for red clover diets. Apparent ruminal N degradability of the diets was unchanged, but true ruminal $\mathrm{N}$ degradability decreased and efficiency of microbial synthesis increased with red clover diets compared with grass silage diets. Omasal canal flows of AA, except those for Met and Cys, were on average $20 \%$ higher for red clover than grass silage diets. Omasal canal digesta concentrations of Leu, Phe, branched-chain, and essential AA were higher but those of Met lower for red clover than for grass silage diets. Plasma AA concentrations, except for His (unchanged) and Met (lower), were higher for red clover than for grass diets. However, none of
\end{abstract}

Received March 27, 2009.

Accepted July 8, 2009.

${ }^{1}$ Corresponding author: aila.vanhatalo@helsinki.fi these AA-related variables were affected by forage maturity. Total digestibility of $\mathrm{N}$ and excretion of $\mathrm{N}$ in the urine were higher for red clover than for grass diets and decreased with advancing maturity. It was concluded that despite the higher total AA supply of cows fed red clover versus grass silage diets, further milk production responses on red clover diets were compromised by an inadequate supply of Met as evidenced by lower Met concentration in the AA profile of omasal digesta and plasma.

Key words: dairy cow, red clover silage, nitrogen metabolism, amino acid supply

\section{INTRODUCTION}

Red clover (Trifolium pratense) is the major forage legume available for silage production in northern Europe. Although grass species such as ryegrass (Lolium perenne), timothy (Phleum pratense), and meadow fescue (Festuca pratensis) are predominantly used in grassland farming, red clover may play an increasingly significant role in future silage production because of its $\mathrm{N}_{2}$ fixing ability. In spite of the relative ease of management of perennial grasses compared with legumes (Harrison et al., 2003), utilization of atmospheric $\mathrm{N}$ in terms of silage production may become attractive because intensive grassland production is largely dependent on fossil fuel-based $\mathrm{N}$ fertilizers.

Despite the beneficial contribution of legumes to forage DMI, animal performance (Heikkilä et al., 1996; Albrecht and Beauchemin, 2003), and the N economy of silage production, conversion of feed $\mathrm{N}$ into milk $\mathrm{N}$ in milk production trials has often been lower on red clover than grass silage diets (Bertilsson and Murphy, 2003; Dewhurst et al., 2003a) because red clover typically contains more CP than grasses. Metabolic studies on the fate of $\mathrm{N}$ in lactating cows comparing red clover and grass silage diets are few. According to Dewhurst et al. (2003b), a red clover silage diet increased microbial energetic efficiency compared with grass diets, but the improved N-use efficiency was considered quite small relative to the high $\mathrm{N}$ intake of the cows fed red clover. On the other hand, with equal DM and $\mathrm{N}$ intakes be- 
tween grass-red clover and sole grass silage diets, the red clover-containing diet increased postruminal NAN flow, reduced $\mathrm{N}$ degradability in the rumen, and slightly increased conversion of feed $\mathrm{N}$ into milk $\mathrm{N}$ (Vanhatalo et al., 2006).

The supply and utilization of nutrients in dairy cows on forage-based diets is affected by numerous factors, of which maturity stage of herbage at harvesting is of major importance. It affects the energy value of forage and thus also utilization of $\mathrm{N}$ in the rumen, which is largely dependent on the energy available for microbial protein synthesis. The effects of forage maturity on grass silage intake and milk production are well known (Rinne, 2000; Harrison et al., 2003) but data concerning the maturity effects of red clover silage are scarce.

Previous metabolic studies comparing red clover and grass silage diets (Dewhurst et al., 2003b; Vanhatalo et al., 2006) did not include measurements on the amount and profile of AA entering the lower tract or urinary or fecal excretion of $\mathrm{N}$. These measurements are of paramount importance as a basis for effective supplementation of forage diets to avoid excessive $\mathrm{N}$ excretion into the environment. The need for development of sustainable milk production systems together with tightening environmental regulations warrant further studies on $\mathrm{N}$ metabolism of legume and grass silage-based diets.

This study was designed to investigate the effects of plant species (red clover vs. grass) and forage maturity at primary harvest (early vs. late) on $\mathrm{N}$ metabolism in the rumen and postruminal AA supply in terms of omasal flows of microbial protein and AA in dairy cows. A factorial arrangement of treatments allowed evaluation of possible interactions between plant species and stage of maturity of forages. The fifth treatment, comprising a 1:1 mixture of late-cut grass silage and early-cut red clover silage, represented a diet applicable to practical farming, in which red clover and grass are largely grown as mixed swards. Dietary effects on plasma AA and energy metabolites as well as milk production were also investigated. Data on milk fatty acid composition have been reported earlier (Vanhatalo et al., 2007), and data on fiber digestion kinetics are reported in the companion paper (Kuoppala et al., 2009).

\section{MATERIALS AND METHODS}

\section{Experimental Silages, Animals, and Diets}

Experimental silages were harvested from the firstyear stands grown in Jokioinen, Finland $\left(60^{\circ} 49^{\prime} \mathrm{N}\right.$, $23^{\circ} 28^{\prime} \mathrm{E}$ ) during 2003. Silages were prepared from primary growths of mixed timothy (cv. Tammisto II)meadow fescue (cv. Antti) and pure red clover (cv. Jokioinen) stands and harvested at early and late stages of maturity. The mixed grass crop received $80 \mathrm{~kg}$ of $\mathrm{N}$ and $5 \mathrm{~kg}$ of $\mathrm{K}$ per ha in spring but the red clover crop was not fertilized. The grass crops were harvested on June 17 (early heading) and June 26 (heading), and the red clover crops on July 2 (preflowering) and July 16 (early flowering), respectively. The timing of the harvests was indented to produce a 5-percentage-unit difference in the concentration of digestible OM in DM of the silages between the early and late cuts of the plant species. All forages were cut using a mower conditioner, wilted slightly, and then harvested using a precision-chop forage harvester. Crops were ensiled using a formic-acid based additive (AIV 2 Plus, Kemira GrowHow Ltd., Helsinki, Finland, containing, per kilogram of additive, $760 \mathrm{~g}$ of formic acid and $55 \mathrm{~g}$ of ammonium formate) applied at a rate of $5 \mathrm{~L} / \mathrm{t}$ of grass or $6 \mathrm{~L} / \mathrm{t}$ of red clover in bunker silos (grass) or clamps (red clover). A relatively short wilting period (3 h for grass and 7 $\mathrm{h}$ for red clover) was used to minimize the variation in DM content and fermentation quality between the experimental silages.

Five multiparous Finnish Ayrshire cows equipped with rumen cannulas (Bar Diamond Inc., Parma, ID), averaging (mean \pm SD) $77 \pm 29$ DIM and $620 \pm 71 \mathrm{~kg}$ of BW at the beginning and $655 \pm 43 \mathrm{~kg}$ at the end of the study, were randomly assigned to treatments within a $5 \times 5$ Latin square. The 5 treatments consisted of the 4 experimental silages and a treatment comprising a 1:1 mixture (DM basis) of late-cut grass silage and earlycut red clover silage. Each period lasted $21 \mathrm{~d}$, with an adaptation period from $\mathrm{d} 1$ to 12 followed by a sampling period from d 13 to 21. Cows were given ad libitum access to silage allowing 5 to $10 \%$ for refusals. During the sampling period, however, the intake of silage was restricted to $95 \%$ of the ad libitum consumption obtained during the 7 previous days to avoid refusals. The standard concentrate fed at a rate of $9 \mathrm{~kg} / \mathrm{d}$ (as-fed basis) contained barley (40.5\%), oats $(40 \%)$, rapeseed expeller (16\%, Mildola Ltd., Kirkkonummi, Finland), and a proprietary vitamin and mineral supplement (3.5\%) called Tarmo (Melica Finland, Vaasa, Finland), which contained $0.6 \% \mathrm{Ca}, 2 \% \mathrm{P}, 6.5 \% \mathrm{Na}$, and $6.5 \% \mathrm{Mg}$ and (per kg) 200,000 IU of vitamin A, 40,000 IU of vitamin D3, and $580 \mathrm{mg}$ of vitamin E. Because of a very high content of $\mathrm{Ca}$ in red clover, the $\mathrm{Ca}$ intake between the grass and clover diets was balanced by additional mineral supplements sprinkled on top of concentrates containing high (Onni $250 \mathrm{~g} / \mathrm{d}$; Melica Finland) or low Ca concentration (Viher-Hertta Minera Muro, $100 \mathrm{~g} / \mathrm{d}$; Suomen Rehu Ltd., Helsinki, Finland). The high-Ca supplement contained $20.5 \% \mathrm{Ca}, 2.7 \% \mathrm{P}, 8.5 \% \mathrm{Na}$ and $7.2 \% \mathrm{Mg}$, and (per $\mathrm{kg}$ ) 220,000 IU of vitamin A, 40,000 IU of vitamin $\mathrm{D}_{3}$ and $550 \mathrm{mg}$ of vitamin $\mathrm{E}$. The low-Ca supplement contained $16 \% \mathrm{Ca}, 6.4 \% \mathrm{P}, 9 \% \mathrm{Na}$, and $8 \%$ 
$\mathrm{Mg}$, and (per kg) 150,000 IU of vitamin A, 100,000 IU of vitamin $\mathrm{D}$, and $950 \mathrm{mg}$ of vitamin $\mathrm{E}, 530 \mathrm{mg}$ of $\mathrm{Cu}$, $20 \mathrm{mg}$ of Se, 4,200 $\mathrm{mg}$ of $\mathrm{Zn}, 20 \mathrm{mg}$ of Mo, $15 \mathrm{mg}$ of Co, 2,250 $\mathrm{mg}$ of $\mathrm{Mn}$, and $140 \mathrm{mg}$ of I. In addition, the grass-fed cows were given $100 \mathrm{~g}$ of $\mathrm{CaCO}_{3}$. Cows were housed in tie stalls and had continuous access to water. All feeds were given individually 4 times daily at 0600, 0900, 1800, and $2000 \mathrm{~h}$, and cows were milked twice daily at 0700 and $1700 \mathrm{~h}$. All experimental procedures were approved by the local animal care and use committee.

\section{Sampling, Recordings, and Chemical Analyses}

Feed intake and milk yield were recorded daily throughout the experiment, but only measurements on d 18 to 21 are reported in the current paper. Daily samples of experimental silages and concentrates were collected during this time and pooled to provide composite samples for analysis of DM, ash, N, NDF, and indigestible NDF. Silage samples were also analyzed for $\mathrm{pH}$, ammonia, and VFA. Milk samples were collected from 4 consecutive milkings on d 18 to 20 and analyzed for fat, protein, lactose, and urea. Feed and milk samples were analyzed using standard procedures as described previously (Ahvenjärvi et al., 2002).

To assess ruminal fermentation, liquid samples of 100 to $150 \mathrm{~mL}$ were obtained on d 14 before the morning meal and at 1.5, 3, 4.5, 6, 7.5, 9, and $10.5 \mathrm{~h}$ thereafter via the rumen cannula using a perforated plastic tube. Samples were immediately measured for $\mathrm{pH}$ and then prepared for the determination of ammonia and VFA as described by Ahvenjärvi et al. (2002). Samples were stored at $-20^{\circ} \mathrm{C}$ before analysis. For the VFA analysis, samples were pooled over the sampling times to provide one sample for each cow per period.

Detailed description of the total collection of feces and urine on d 18 to 21 as well as description of the omasal sampling technique applied to obtain samples from the omasal canal to determine total and ruminal digestibility of diets, respectively, is given elsewhere (Ahvenjärvi et al., 2000). In brief, indigestible NDF, Yb-acetate, and Cr-EDTA (Binnerts et al., 1968) were used as markers for the large particles, small particles, and liquid phase, respectively. To facilitate rapid equilibration of the external marker concentration in the rumen, a priming dose of $\mathrm{Yb}$-acetate and Cr-EDTA $(3.1 \mathrm{~g} / \mathrm{d}$ of $\mathrm{Yb}$ and $4.2 \mathrm{~g} / \mathrm{d}$ of $\mathrm{Cr}$, respectively) was administered directly into the rumen via the rumen cannula at $1800 \mathrm{~h}$ on $\mathrm{d}$ 15. Thereafter, continuous infusion of the markers (2.4 $\mathrm{g}$ of $\mathrm{Yb} / \mathrm{d}$ and $2.8 \mathrm{~g}$ of $\mathrm{Cr} / \mathrm{d}$, respectively) dissolved in $6 \mathrm{~L}$ of distilled water was administered until the end of each period using a peristaltic pump (502 S, WatsonMarlow, Falmouth, UK). Separate lines were used for each of the markers to avoid a potential precipitation of the markers. Omasal canal spot samples of $500 \mathrm{~mL}$ were collected using the omasal sampling device 3 times daily on d 18 to 21 starting at 0600, 1000, and $1400 \mathrm{~h}$ on d 18. On the 3 following days, digesta sampling advanced $1 \mathrm{~h}$ each day such that samples represented each hour during the 12-h daytime feeding cycle. Samples were frozen immediately after the sampling, stored at $-20^{\circ} \mathrm{C}$ until thawed at room temperature, and pooled over sampling times to form 1 sample per cow per period. The fractioning of the samples into large particles, small particles, and liquid phase and the analyzing of the chemical composition of fecal and digesta samples as well as markers used were described in detail previously (Ahvenjärvi et al., 2002) except for AA analyses, which were described by Korhonen et al. (2000).

The flow of microbial $\mathrm{N}$ from the rumen was estimated using $17.5 \mathrm{~g} / \mathrm{d}$ of ammonium sulfate (Isotec Inc., Miamisburg, OH) with $10 \%$ enrichment of ${ }^{15} \mathrm{~N}(371 \mathrm{mg}$ of ${ }^{15} \mathrm{~N} / \mathrm{d}$ ) as a marker. Infusion of the marker dissolved into the infusion solution of ytterbium started $48 \mathrm{~h}$ before the first sampling. Before the beginning of the marker infusion, samples of rumen contents of each cow were taken on d 11 during the first period to determine the background abundance of ${ }^{15} \mathrm{~N}$. Samples for bacterial separation $(500 \mathrm{~mL})$ were taken from reticular digesta at $1500,1200,0900$, and $0600 \mathrm{~h}$ on d 18, 19, 20, and 21 , respectively. Immediately after collection, samples were centrifuged and the supernatant was decanted through 2 layers of cheesecloth. Differential centrifugation of these samples is described in detail elsewhere (Ahvenjärvi et al., 2000). Measurement of ${ }^{15} \mathrm{~N}$ enrichment in bacterial pellet and omasal samples was similar to that reported by Ahvenjärvi et al. (2002).

Blood samples were taken using evacuated blood collection tubes (Vacuette, Greiner Labortechnic GmbH, Krensmunster, Austria) containing Li-EDTA (for AA, glucose, NEFA, and BHBA analysis) and Li-heparin (for acetic acid analysis) from one coccygeal vessel considered to be arterial blood and one superficial epigastric vein considered to be venous blood at 0600, 0900, and $1200 \mathrm{~h}$ on d 21 of each period. Tubes were chilled in an ice bath and centrifuged (at $872 \times g$ and $4^{\circ} \mathrm{C}$ for $15 \mathrm{~min}$ ) immediately after sampling. For analysis, plasma samples were pooled across sampling times to provide 1 sample per cow per period. Details of analysis of the plasma samples has been described previously (Korhonen et al., 2000).

\section{Calculations and Statistical Analyses}

The chemical composition of omasal canal true digesta and the DM flow entering the omasal canal were calculated based on a triple marker method (France 
and Siddons, 1986) utilizing 3 indigestible markers (indigestible NDF, Yb, and $\mathrm{Cr}$ ). The amount of VFA entering the omasal canal was subtracted from total OM flow as described before (Ahvenjärvi et al., 2002). Nonammonia $\mathrm{N}$ was calculated by difference between total $\mathrm{N}$ and ammonia $\mathrm{N}$. Bacterial $\mathrm{N}$ flow from the rumen as well as apparent and true $\mathrm{N}$ degradability in the rumen was calculated similarly to that in Ahvenjärvi et al. (2002). Daily N retention was calculated by subtracting the sum of $\mathrm{N}$ excretion in milk, feces, and urine from $\mathrm{N}$ intake. Dietary $\mathrm{CP}$ balance in the rumen (i.e., a theoretical CP concentration, which provides a sufficient quantity of rumen degradable $\mathrm{N}$ without any net ammonia losses) was calculated as the total NAN flow entering the omasal canal divided by DMI and multiplied by 6.25 . This theoretical estimate is based on the assumption that in a steady state all fluxes entering and escaping a system must be in balance. Applying this principle to the rumen environment, no ammonia $\mathrm{N}$ is absorbed from or escapes the rumen with digesta flow when the NAN flow entering the omasal canal is equal to $\mathrm{N}$ intake.

Assessment of mammary plasma flow, extractions, arteriovenous (AV) differences, and mammary uptakes of AA have been described elsewhere (Vanhatalo et al., 1999). In brief, mammary plasma flow was estimated by reference to Phe and Tyr output in milk protein by the application of the Fick principle. Extraction and mammary uptake values were calculated as AV difference/arterial concentration and AV difference $x$ mammary plasma flow, respectively.

Data were subjected to ANOVA for a $5 \times 5$ Latin square design with a statistical model that included the fixed effects of animal, period, and treatment using the MIXED procedure of SAS (SAS for Windows, version 8.2, SAS Institute, Cary, NC). Measurements were lost for one cow on the mixed forage diet during the first period because of a digestive disorder. In addition, blood samples from one cow fed the late-cut red clover diet during the first period were lost for reasons unrelated to treatments. For treatment comparisons, the sum of squares for experimental diets were further divided into preplanned single degree of freedom comparisons to study the effects of plant species (grass silage vs. red clover silage), stage of maturity of forage (early- vs. late-cut silages), and their interaction (plant species $x$ forage maturity), and the effect of a mixed forage diet versus sole forages. Treatment effects were declared significant at $P \leq 0.05$, and tendencies were noted for $P \leq$ 0.10 . Results are reported as least squares means.

\section{RESULTS}

\section{Silage Composition, Feed Intake, Milk Yield, and Diet Digestibility}

The chemical composition of the experimental feeds is given in Table 1. All silages contained low concentra-

Table 1. Chemical composition of the concentrate and the experimental feeds at early and late growth stages

\begin{tabular}{|c|c|c|c|c|c|}
\hline \multirow[b]{2}{*}{ Item } & \multicolumn{2}{|c|}{ Grass silage } & \multicolumn{2}{|c|}{ Red clover silage } & \multirow[b]{2}{*}{ Concentrate } \\
\hline & Early & Late & Early & Late & \\
\hline $\mathrm{pH}$ & 4.04 & 3.97 & 4.15 & 4.10 & \\
\hline $\mathrm{DM}, \%$ & 24.9 & 25.7 & 21.4 & 21.2 & 89.0 \\
\hline \multicolumn{6}{|l|}{$\%$ of $\mathrm{DM}$} \\
\hline Ash & 8.6 & 7.5 & 10.2 & 9.3 & 5.4 \\
\hline $\mathrm{CP}$ & 13.4 & 11.1 & 21.2 & 18.1 & 16.7 \\
\hline $\mathrm{NDF}$ & 50.0 & 57.0 & 37.5 & 46.3 & 20.5 \\
\hline Water-soluble carbohydrates & 6.1 & 3.1 & 1.7 & 2.0 & \\
\hline Lactic acid & 6.2 & 5.6 & 5.0 & 3.8 & \\
\hline VFA & 3.6 & 3.4 & 3.5 & 3.5 & \\
\hline \multicolumn{6}{|l|}{$\%$ of total $\mathrm{N}$} \\
\hline Soluble N & 56.1 & 53.6 & 27.7 & 28.8 & \\
\hline Ammonia N & 4.4 & 4.4 & 2.5 & 3.2 & \\
\hline \multicolumn{6}{|l|}{$\mathrm{AA}, \mathrm{g} / 100 \mathrm{~g}$ of $\mathrm{CP}$} \\
\hline Arg & 3.5 & 4.1 & 4.7 & 4.5 & 5.7 \\
\hline His & 1.9 & 1.9 & 2.0 & 2.3 & 2.5 \\
\hline Ile & 4.1 & 3.8 & 4.0 & 4.2 & 3.6 \\
\hline Leu & 7.8 & 7.4 & 8.4 & 8.2 & 7.4 \\
\hline Lys & 4.8 & 4.8 & 5.3 & 5.1 & 4.0 \\
\hline Met & 1.7 & 1.6 & 1.6 & 1.6 & 2.0 \\
\hline Phe & 4.5 & 5.1 & 5.6 & 4.6 & 4.6 \\
\hline Thr & 3.8 & 4.2 & 3.9 & 4.6 & 4.1 \\
\hline Val & 4.8 & 4.8 & 4.6 & 5.0 & 4.6 \\
\hline Total $\mathrm{AA}^{1}$ & 78.0 & 81.2 & 85.4 & 89.3 & 95.3 \\
\hline
\end{tabular}

${ }^{1}$ Total $\mathrm{AA}=$ essential + nonessential AA. 
tions of fermentation acids and a low proportion of ammonia in total N. However, DM concentration of silages and content of soluble $\mathrm{N}$ in total $\mathrm{N}$ were lower for red clover than for grass silages. Concentration of NDF was higher and that of $\mathrm{CP}$ much lower for grass than for red clover silages. Advancing maturity increased NDF and decreased $\mathrm{CP}$ concentration of the silages. Concentration of digestible $\mathrm{OM}$ in silage DM was lower for red clover than for grass silages.

Data on feed intake, milk production, and diet digestibility of $\mathrm{OM}$ is given in Table 2. Grass silage DMI tended to decrease but that of red clover silages tended to increase with advancing maturity $(P<0.10$ for plant species $\times$ growth stage interaction). Feeding a 1:1 mixture of early-cut red clover and late-cut grass silage led to a higher $(P<0.05)$ DMI than feeding either of these silages as the sole forage in the diet. Despite the differences in the silage DMI, milk and ECM yields were unchanged $(P>0.10)$ among treatments. Milk protein and fat concentrations were higher $(P \leq 0.01)$ and lactose and urea concentrations lower $(P \leq 0.05)$ for grass compared with red clover silage diets. Digestibility of OM in the rumen or total tract did not differ $(P>0.10)$ between plant species but decreased $(P \leq$ $0.001)$ or tended to decrease $(P<0.10)$ with advancing maturity.

\section{Rumen Fermentation}

Because there was no significant diurnal variation in rumen $\mathrm{pH}$ or ammonia $\mathrm{N}$ concentrations among dietary treatments $(P>0.05$ for dietary treatment $\times$ time interaction), data for these variables are presented over sampling times similarly to VFA concentrations (Table 3 ). However, diurnal variation of rumen fluid $\mathrm{pH}$ and ammonia $\mathrm{N}$ concentrations are presented in more detail in the companion paper (Kuoppala et al., 2009). In general, rumen $\mathrm{pH}$ did not differ between plant species $(P>0.10)$, but tended to increase $(P<0.10)$ with advancing maturity of forages. Average concentrations of ammonia $\mathrm{N}$ and total VFA in the rumen were higher $(P \leq 0.001)$ for red clover than for grass silage diets. Delaying the harvest decreased $(P<0.05)$ total VFA concentration. The molar proportion of acetate was higher $(P<0.001)$ and proportions of propionate, butyrate, and valerate were lower $(P \leq 0.001)$ for red clover than for grass silage diets. Delaying the harvest increased $(P<0.01)$ the molar proportion of acetate and decreased $(P \leq 0.05)$ those of butyrate, valerate, and caproate.

\section{N Metabolism}

Intake of $\mathrm{N}$ was higher $(P<0.001)$ for red clover than for grass silage diets and decreased $(P<0.05)$ with advancing maturity of silages (Table 4 ). Flows of total NAN and dietary NAN entering the omasal canal were higher $(P \leq 0.01)$ for red clover than for grass silage diets but they were not affected $(P>0.10)$ by the maturity stage of silages. However, microbial NAN flow and the amount of $\mathrm{N}$ excreted in feces decreased with advancing maturity for grass diets but increased for red clover diets $(P \leq 0.05$ for plant species $\times$ growth stage interaction). Apparent ruminal $\mathrm{N}$ digestibility of the diets was not affected $(P>0.10)$ by treatments, but true ruminal $\mathrm{N}$ digestibility decreased $(P<0.05)$

Table 2. Effects of dietary forage source and stage of maturity on feed intake, milk yield, and milk composition

\begin{tabular}{|c|c|c|c|c|c|c|c|c|c|c|}
\hline Item & \multicolumn{2}{|c|}{ Grass silage } & $\begin{array}{c}\text { Mixed } \\
\text { forage diet }\end{array}$ & \multicolumn{2}{|c|}{ Red clover silage } & SEM & \multicolumn{4}{|c|}{ Contrasts, $P$-value ${ }^{1}$} \\
\hline \multicolumn{11}{|l|}{ DMI, kg/d } \\
\hline Concentrate & 7.6 & 7.8 & 7.4 & 7.4 & 8.0 & 0.48 & & & & \\
\hline Total & 21.2 & 20.1 & 21.5 & 18.8 & 20.2 & 0.59 & $\dagger$ & NS & $\dagger$ & * \\
\hline \multicolumn{11}{|l|}{ Yield, kg/d } \\
\hline Protein, g/d & 874 & 824 & 865 & 815 & 828 & 29.0 & NS & NS & NS & NS \\
\hline Lactose, $\mathrm{g} / \mathrm{d}$ & 1,248 & 1,191 & 1,307 & 1,307 & 1,284 & 47.4 & NS & NS & NS & NS \\
\hline Fat, g/d & 1,093 & 1,034 & 1,058 & 997 & 1,054 & 30.5 & NS & NS & $\dagger$ & NS \\
\hline \multicolumn{11}{|c|}{ Milk composition, $\%$ of milk } \\
\hline Protein & 3.26 & 3.26 & 3.15 & 3.04 & 3.08 & 0.038 & $* * *$ & NS & NS & NS \\
\hline Lactose & 4.61 & 4.66 & 4.69 & 4.70 & 4.67 & 0.021 & $*$ & NS & NS & NS \\
\hline Fat & 4.09 & 4.12 & 3.86 & 3.74 & 3.94 & 0.076 & $* *$ & NS & NS & NS \\
\hline
\end{tabular}

${ }^{1}$ Probability of the effects due to plant species (grass silage vs. red clover silage; C1), growth stage (early vs. late cut; C2), and their interaction (C3) and comparison between sole forages and a mixture (1:1) of late-cut grass silage and early-cut red clover silage (C4), respectively.

$\dagger P \leq 0.10 ;{ }^{*} P \leq 0.05 ;{ }^{* *} P \leq 0.01 ;{ }^{* * *} P \leq 0.001 ; \mathrm{NS}=$ not significant $(P>0.10)$. 
Table 3. Effects of dietary forage source and stage of maturity on rumen fermentation and organic matter digestibility

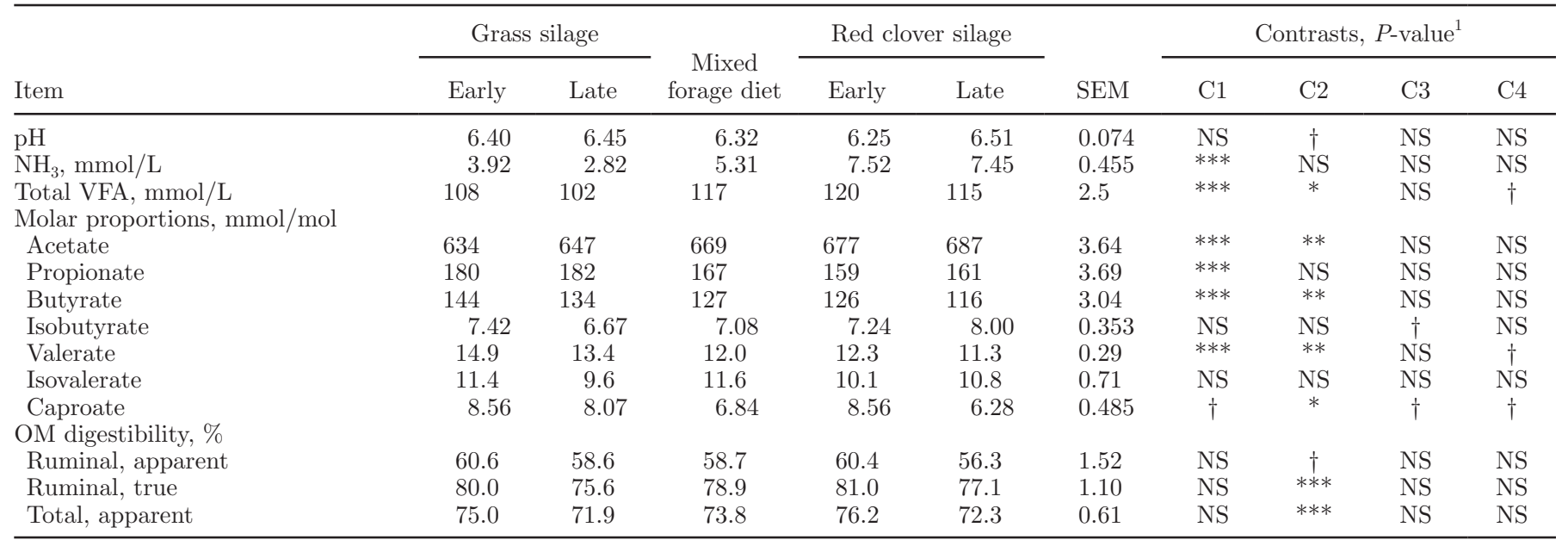

${ }^{1}$ Probability of the effects due to plant species (grass silage vs. red clover silage; C1), growth stage (early vs. late cut; C2), and their interaction (C3) and comparison between sole forages and a mixture (1:1) of late-cut grass silage and early-cut red clover silage (C4), respectively.

$\dagger P \leq 0.10 ;{ }^{*} P \leq 0.05 ;{ }^{* *} P \leq 0.01 ;{ }^{* * *} P \leq 0.001 ; \mathrm{NS}=$ not significant $(P>0.10)$.

and efficiency of microbial synthesis increased $(P<$ $0.05)$ with red clover diets compared with grass silage diets. Total-tract digestibility of $\mathrm{N}$ was higher $(P<$ $0.01)$ for red clover diets compared with grass diets and decreased $(P<0.01)$ with advancing maturity for both plant species. Excretion of $\mathrm{N}$ in the urine was higher $(P<0.001)$ and calculated $\mathrm{N}$ balance tended to be higher $(P<0.10)$ for red clover diets than for grass diets, and they decreased $(P \leq 0.05)$ with advancing maturity of silages. Calculated dietary $\mathrm{CP}$ balance in the rumen was higher $(P<0.001)$ for red clover than for grass silage diets and decreased $(P<0.10)$ with advancing maturity of both plant species. Feeding a mixed forage diet led to an intermediate $(P<0.05) \mathrm{N}$ intake, but higher $(P \leq 0.10)$ total and microbial NAN flows from the rumen, higher $(P<0.01) \mathrm{N}$ excretion in feces, and intermediate $(P<0.01) \mathrm{N}$ excretion in the urine compared with feeding the silages as the sole forage in the diet.

The flows of individual AA entering the omasal canal are presented in Table 5. The flows of all individual AA except Met and Cys were higher $(P \leq 0.01)$ for red clover than for grass diets, and except for Ala they were unchanged $(P>0.10)$ despite the advancing growth stage of silages. The flows of some AA [Ile, Val, Ala, Pro, and branched-chain AA (BCAA)] were higher $(P$ $\leq 0.05)$ for the mixed forage diet than for the respective sole forage diets. The flows of BCAA, essential AA (EAA), nonessential AA (NEAA), and total AA (TAA) as well as the percentage of TAA in $\operatorname{diet} \mathrm{CP}$ were higher $(P \leq 0.05)$ for red clover than for grass diets, but they were not affected $(P>0.10)$ by the harvest time of silages.
The AA profile of omasal digesta is shown in Table 6 . The concentrations of Leu, Phe, BCAA, and EAA were higher $(P \leq 0.05)$ but those of Met lower $(P<0.05)$ for red clover compared with grass silage diets. Further, delaying the harvest increased the concentration of Thr in omasal digesta of grass silage-fed cows but the opposite was true for red clover-fed cows $(P<0.05)$.

\section{Plasma AA and Other Metabolites}

Plasma AA and energy metabolite concentrations representing arterial blood are shown in Table 7 . Concentrations of BCAA, TAA, and most EAA, except for His and Trp (unchanged, $P>0.10$ ) and Met (lower, $P<0.01)$, were higher $(P \leq 0.01)$ for red clover than for grass diets but were not affected $(P>0.10)$ by the harvest time of silages. For NEAA, concentrations of Cit, Orn, and Pro were higher $(P \leq 0.05)$ and those of Ala and Glu lower $(P \leq 0.05)$ for red clover than for grass diets. The proportion of EAA in arterial TAA concentration was higher $(P<0.001)$ for red clover than for grass diets. Concentrations of urea and NEFA $(P<0.05)$ were higher for red clover than for grass diets but concentrations of glucose, BHBA, and insulin were not affected $(P>0.10)$ by treatments. Concentration of arterial acetate decreased with advancing maturity of grass diets but increased with that of red clover diets $(P<0.05$ for plant species $\times$ growth stage interaction).

Arteriovenous differences, extraction efficiencies, and uptakes of AA by the mammary gland were generally not affected by treatments (data not shown) except for a lower $(P \leq 0.05)$ AV difference of Glu, lower extrac- 
Table 4. Effects of dietary forage source and stage of maturity on omasal $\mathrm{N}$ flow and $\mathrm{N}$ digestibility

\begin{tabular}{|c|c|c|c|c|c|c|c|c|c|c|}
\hline Item & \multicolumn{2}{|c|}{ Grass silage } & $\begin{array}{l}\text { Mixed } \\
\text { forage diet }\end{array}$ & \multicolumn{2}{|c|}{ Red clover silage } & SEM & \multicolumn{4}{|c|}{ Contrasts, $P$-value ${ }^{1}$} \\
\hline $\begin{array}{l}\text { Intake, } \mathrm{g} / \mathrm{d} \\
\text { NAN flow entering the } \\
\text { omasal canal, } \mathrm{g} / \mathrm{d}\end{array}$ & 488 & 419 & 559 & 581 & 563 & 14.2 & $* * *$ & $*$ & NS & $*$ \\
\hline Total & 477 & 409 & 555 & 531 & 532 & 28.2 & $* *$ & NS & NS & $\dagger$ \\
\hline Microbial & 333 & 279 & 355 & 315 & 342 & 17.8 & NS & NS & $*$ & * \\
\hline $\mathrm{N}$ balance, ${ }^{2} \mathrm{~g} / \mathrm{d}$ & 62.8 & 44.8 & 53.7 & 71.1 & 62.3 & 6.00 & $\dagger$ & $*$ & NS & NS \\
\hline $\mathrm{N}$ digestibility, \% & & & & & & & & & & \\
\hline Ruminal, apparent & 1.2 & 1.7 & 0.3 & 8.0 & 4.4 & 4.10 & NS & NS & NS & NS \\
\hline Ruminal, true & 70.6 & 69.0 & 64.5 & 63.1 & 66.1 & 1.89 & $*$ & NS & NS & NS \\
\hline Total, apparent & 68.1 & 66.8 & 68.9 & 73.2 & 70.3 & 0.58 & $* * *$ & $* *$ & NS & NS \\
\hline Microbial efficiency & & & & & & & & & & \\
\hline
\end{tabular}

${ }^{1}$ Probability of the effects due to plant species (grass silage vs. red clover silage; C1), growth stage (early vs. late cut; C2), and their interaction (C3) and comparison between sole forages and a mixture (1:1) of late-cut grass silage and early-cut red clover silage (C4), respectively.

${ }^{2} \mathrm{~N}$ balance $=\mathrm{N}$ intake $-(\mathrm{N}$ in milk $+\mathrm{N}$ in feces $+\mathrm{N}$ in urine $)$.

${ }^{3} \mathrm{OM}$ apparently digested in the rumen.

${ }^{4} \mathrm{OM}$ truly digested in the rumen.

${ }^{5}$ Dietary $\mathrm{CP}$, where $\mathrm{N}$ intake equals total NAN flow entering the omasal canal.

$\dagger P \leq 0.10 ;{ }^{*} P \leq 0.05 ;{ }^{*} P \leq 0.01 ; * * * P \leq 0.001 ; \mathrm{NS}=$ not significant $(P>0.10)$.

Table 5. Effects of dietary forage source and stage of maturity on the flow of AA entering the omasal canal (g/d)

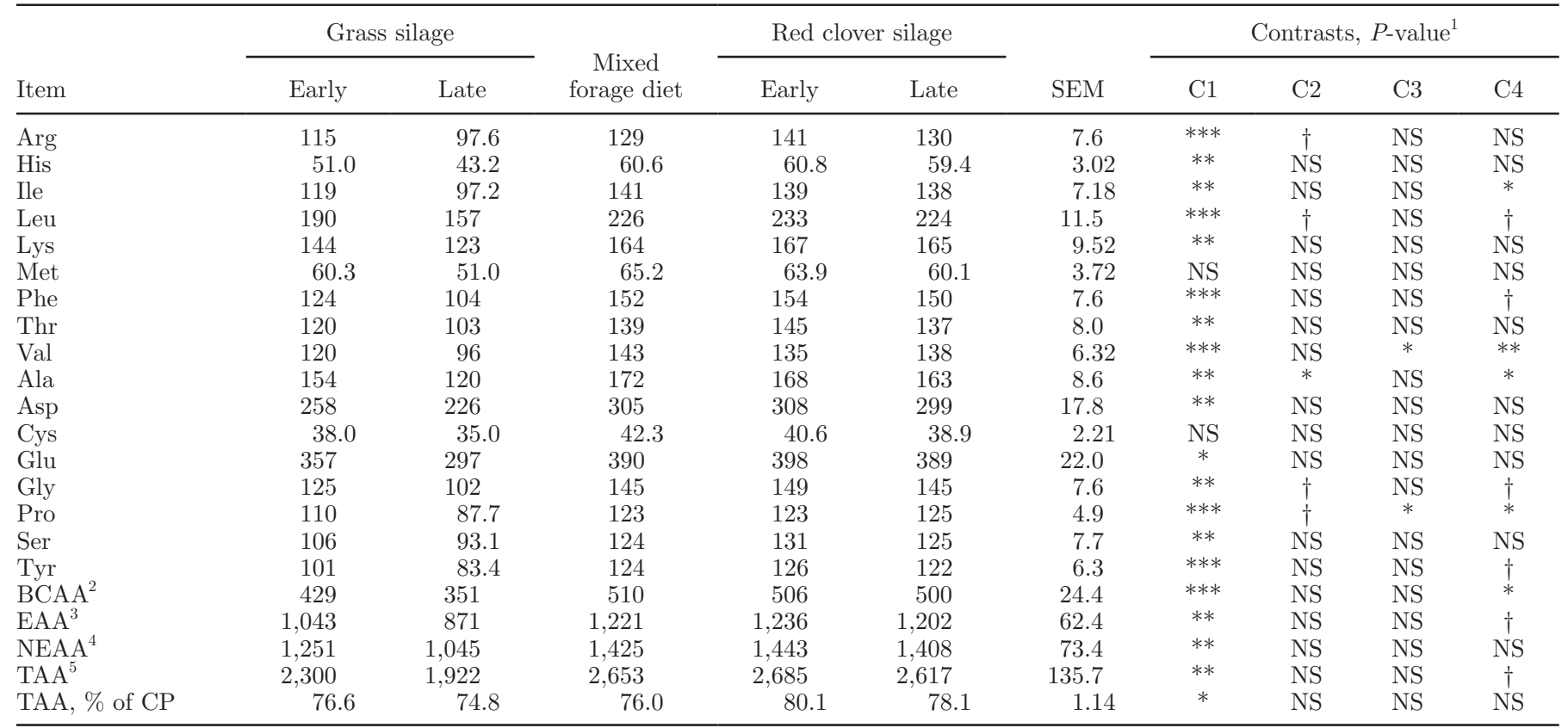

${ }^{1}$ Probability of the effects due to plant species (grass silage vs. red clover silage; C1), growth stage (early vs. late cut; C2), and their interaction (C3) and comparison between sole forages and a mixture (1:1) of late-cut grass silage and early-cut red clover silage (C4), respectively.

${ }^{2} \mathrm{BCAA}=$ branched-chain AA (Val, Ile, and Leu).

${ }^{3} \mathrm{EAA}=$ essential AA (Arg, His, Ile, Leu, Lys, Met, Phe, Thr, Trp, and Val).

${ }^{4}$ NEAA $=$ nonessential AA (Ala, Asn, Asp, Cys, Gln, Glu, Gly, Pro, Ser, and Tyr).

${ }^{5} \mathrm{TAA}=\mathrm{EAA}+\mathrm{NEAA}$.

$\dagger P \leq 0.10 ;{ }^{*} P \leq 0.05 ;{ }^{*} P \leq 0.01 ;{ }^{* *} P \leq 0.001 ; \mathrm{NS}=$ not significant $(P>0.10)$. 
Table 6. Effects of dietary forage source and stage of maturity on the AA profile of omasal digesta (g/100 g of AA)

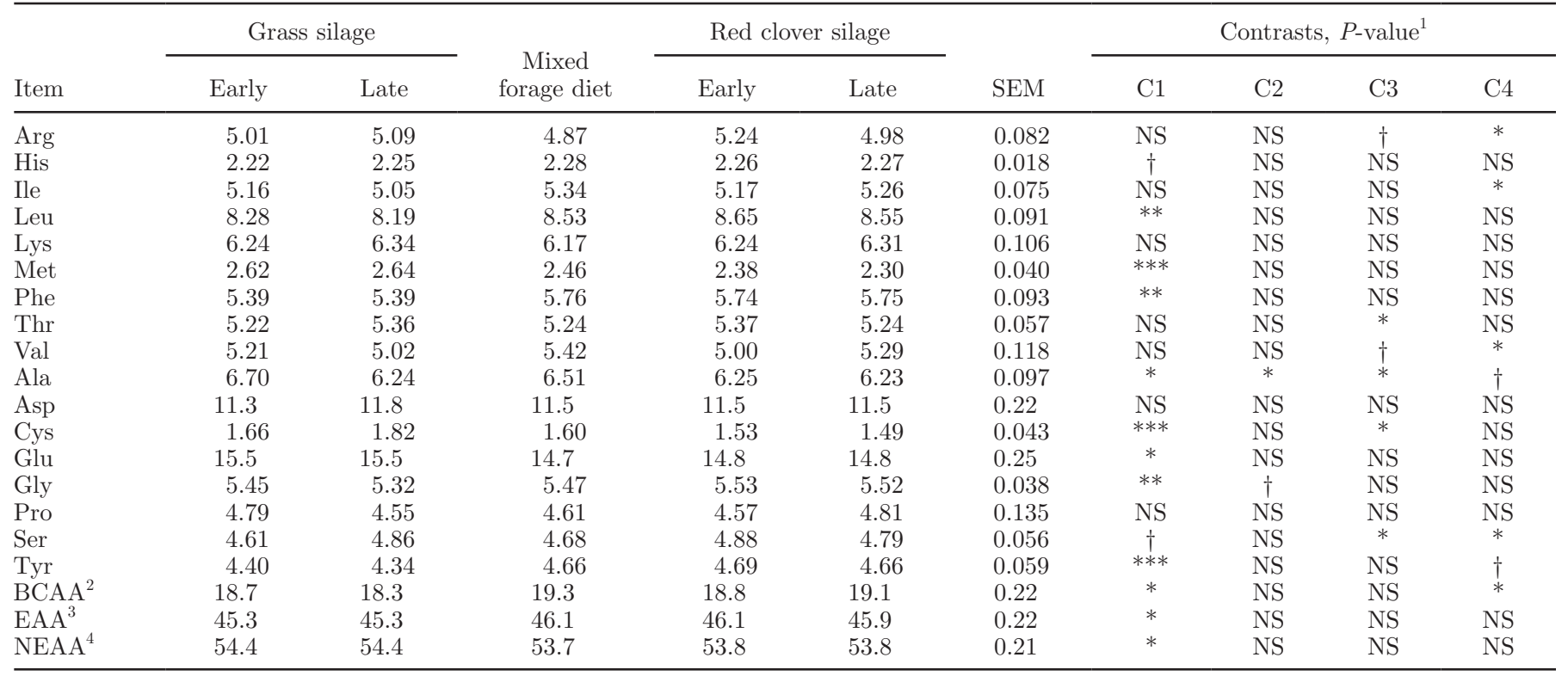

${ }^{1}$ Probability of the effects due to plant species (grass silage vs. red clover silage; C1), growth stage (early vs. late cut; C2), and their interaction (C3) and comparison between sole forages and a mixture (1:1) of late-cut grass silage and early-cut red clover silage (C4), respectively.

${ }^{2} \mathrm{BCAA}=$ branched-chain AA (Val, Ile, and Leu).

${ }^{3} \mathrm{EAA}=$ essential AA (Arg, His, Ile, Leu, Lys, Met, Phe, Thr, Trp, and Val).

${ }^{4} \mathrm{NEAA}=$ nonessential AA (Ala, Asn, Asp, Cys, Gln, Glu, Gly, Pro, Ser, and Tyr).

$\dagger P \leq 0.10 ;{ }^{*} P \leq 0.05 ;{ }^{* *} P \leq 0.01 ;{ }^{* * *} P \leq 0.001 ; \mathrm{NS}=$ not significant $(P>0.10)$.

tion efficiency of Leu, lower uptakes of Met and Glu, and higher $(P<0.05)$ AV difference of Tyr for red clover compared with grass diets. Uptakes of TAA by the mammary gland were $32.9,29.8,26.3,30.6$, and $28.9 \mathrm{~g} / \mathrm{kg}$ of milk (SEM 6.44) for early- and late-cut grass and red clover silages, and the mixed forage diet, respectively. Mammary plasma flows for the respective treatments were $627,778,480,458$, and $655 \mathrm{~L} / \mathrm{d}(\mathrm{SEM}$ 96.4) and they were higher $(P<0.05)$ for grass compared with red clover silage diets.

\section{DISCUSSION}

\section{Silage Composition}

Harvesting of both plant species at 2 maturity stages resulted in calculated ME values of 11.4, 10.8, 10.8, and $9.8 \mathrm{MJ} / \mathrm{kg}$ of DM (MTT, 2006) for early-cut grass, late-cut grass, early-cut silage, and late-cut silage, respectively. All experimental silages were well preserved, with the low concentration of fermentation acids that is typical of silages ensiled with a high application rate of formic acid additive (Jaakkola et al., 2006). The lower proportion of ammonia $\mathrm{N}$ and soluble $\mathrm{N}$ in the red clover compared with grass silage total $\mathrm{N}$ has been found consistently (Heikkilä et al., 1996; Dewhurst et al., 2003b; Vanhatalo et al., 2006) and is attributed to the endogenous presence and activity of polyphenol oxidase (PPO) in red clover inhibiting the proteolysis in the silo (Jones et al., 1995; Lee et al., 2004; Sullivan and Hatfield, 2006).

\section{DMI, Milk Production, and Diet Digestion}

The tendency for increasing silage DMI with advancing maturity of red clover silage in contrast to results found with grass silage diets in this and earlier studies (Rinne, 2000) was an unexpected finding. Factors affecting silage intake potential such as silage digestibility, in silo fermentation characteristics, or DM concentration (Huhtanen et al., 2007) were similar for red clover and grass silages in the present study and do not explain the contrasting intake responses of cows to the maturity stage of these silages as discussed in detail in our companion paper (Kuoppala et al., 2009). It seems obvious that factors affecting silage DMI of pure legume silage differ to some extent from those obtained with grass silage, and further studies on DMI of pure legume silages and especially effects of growth stage of pure legume silages is needed. The higher silage DMI with the mixture of red clover and grass than with either of these silages alone is in agreement with results of Tuori et al. (2002) and Bertilsson and Murphy (2003), and may be considered a positive associative effect of feeding legume and grass silage together. In contrast, other researchers (Dewhurst et al., 2003b; Moorby et 
al., 2009) observed that DMI of pure red clover silage was higher than that of mixed red clover-grass silage or pure grass silage. Discrepancies in the results between these studies may reflect differences in herbage composition between the primary and later cuts as discussed in our companion paper (Kuoppala et al., 2009).

Despite the tendency for lower average silage DMI with red clover than with grass silage diets, milk and ECM yields were unchanged among treatments, suggesting improved feed nutrient utilization for red clover diets. This is supported by the higher digestibility of $\mathrm{OM}$ in the rumen and in the total tract of cows consuming red clover compared with grass silage diets. Even though the digestibility of NDF was lower for red clover, digestibility of the potentially digestible NDF was higher for red clover than for grass silage diets as reported in the companion paper (Kuoppala et al., 2009). The higher plasma NEFA concentrations on red clover than on grass diets may reflect slightly increased use of body reserves on red clover diets, further explaining the unchanged milk yields between the 2 forage sources.

Lower milk fat and protein concentrations for pure red clover compared with grass silage diets were in agreement with some studies (Tuori et al., 2002; Bertilsson and Murphy, 2003), whereas they were unchanged in another study reported by Bertilsson and Murphy (2003) and in the study of Dewhurst et al. (2003b). The lower molar proportion of butyric acid in the rumen of red clover-fed compared with grass-fed cows

Table 7. Effects of dietary forage source and stage of maturity on the arterial plasma AA, urea, and energy metabolite concentrations ( $\mu$ mol/L unless otherwise stated)

\begin{tabular}{|c|c|c|c|c|c|c|c|c|c|c|}
\hline Item & \multicolumn{2}{|c|}{ Grass silage } & $\begin{array}{c}\text { Mixed } \\
\text { forage diet }\end{array}$ & \multicolumn{2}{|c|}{ Red clover silage } & SEM & \multicolumn{4}{|c|}{ Contrasts, $P$-value ${ }^{1}$} \\
\hline $\operatorname{Arg}$ & 71 & 64 & 79 & 88 & 88 & 9.2 & $\dagger$ & NS & NS & NS \\
\hline Ile & 109 & 115 & 144 & 193 & 159 & 16.6 & $* *$ & NS & NS & NS \\
\hline Leu & 104 & 99 & 169 & 228 & 181 & 14.1 & $* * *$ & NS & NS & NS \\
\hline Lys & 74 & 76 & 91 & 111 & 92 & 7.0 & $* *$ & NS & NS & NS \\
\hline Trp & 28 & 18 & 27 & 27 & 21 & 7.3 & NS & NS & NS & NS \\
\hline Thr & 98 & 100 & 125 & 119 & 126 & 8.1 & $*$ & NS & NS & NS \\
\hline Val & 204 & 216 & 270 & 374 & 287 & 26.9 & $*$ & NS & NS & NS \\
\hline Ala & 223 & 207 & 206 & 181 & 183 & 11.6 & $*$ & NS & NS & NS \\
\hline Asn & 54 & 42 & 51 & 46 & 51 & 4.7 & NS & NS & NS & NS \\
\hline Asp & 6.6 & 5.8 & 5.6 & 5.9 & 5.7 & 0.58 & NS & NS & NS & NS \\
\hline Cit & 50 & 52 & 68 & 92 & 82 & 7.9 & $* * *$ & NS & NS & NS \\
\hline Pro & 66 & 63 & 94 & 95 & 107 & 13.8 & $*$ & NS & NS & NS \\
\hline Ser & 96 & 91 & 111 & 87 & 94 & 9.7 & NS & NS & NS & NS \\
\hline $\mathrm{Tau}$ & 38 & 38 & 43 & 36 & 36 & 1.8 & NS & NS & NS & $*$ \\
\hline Tyr & 35 & 36 & 49 & 51 & 47 & 3.2 & *** & NS & NS & NS \\
\hline $\mathrm{BCAA}^{2}$ & 417 & $\begin{array}{r}50 \\
430\end{array}$ & $\begin{array}{r}49 \\
582\end{array}$ & $\begin{array}{r}01 \\
795\end{array}$ & 626 & $\begin{array}{l}0.2 \\
52.9\end{array}$ & $* * *$ & NS & NS & NS \\
\hline $\mathrm{EAA}^{3}$ & 783 & 793 & 1,021 & 1,270 & 1,068 & 71.9 & $* * *$ & NS & NS & NS \\
\hline $\mathrm{NEAA}^{4}$ & 1,083 & 1,019 & 1,131 & 1,087 & 1,069 & 57.4 & NS & NS & NS & NS \\
\hline $\mathrm{TAA}^{5}$ & 1,866 & 1,811 & 2,151 & 2,357 & 2,137 & 120.5 & $* *$ & NS & NS & NS \\
\hline EAA:TAA & 0.42 & 0.43 & 0.47 & 0.54 & 0.50 & 0.013 & $* * *$ & NS & $\dagger$ & NS \\
\hline Urea, mmol/L & 3.02 & 2.84 & 5.10 & 7.10 & 6.93 & 0.301 & $* * *$ & NS & NS & NS \\
\hline Glucose, $\mathrm{mmol} / \mathrm{L}$ & 3.67 & 3.61 & 3.63 & 3.57 & 3.68 & 0.104 & NS & NS & NS & NS \\
\hline NEFA & 105 & 107 & 117 & 131 & 157 & 12.1 & $*$ & NS & NS & NS \\
\hline Acetate, $\mathrm{mmol} / \mathrm{L}$ & 1.34 & 1.03 & 1.20 & 1.30 & 1.48 & 0.084 & $*$ & NS & $*$ & NS \\
\hline $\mathrm{BHBA}, \mathrm{mmol} / \mathrm{L}$ & 1.11 & 0.84 & 0.79 & 1.30 & 0.99 & 0.207 & NS & NS & NS & NS \\
\hline
\end{tabular}


corresponded well with the reduced milk fat with red clover diets in the present study. However, increases in the supply of long-chain fatty acids to the mammary gland presumably because of reduced biohydrogenation of polyunsaturated fatty acids in the rumen of red clover-fed cows (Dewhurst et al., 2003b) may also have inhibited de novo milk fatty acid synthesis and contributed to the reduction in milk fat content in the present study, as proposed earlier (Vanhatalo et al., 2007). The decreased milk protein content in red clover-fed cows may be related to a possible imbalance in the AA profile of postruminal digesta delivered to the lower tract, as will be discussed later. However, cows consumed ME and MP in excess of requirements according to MTT (2006).

\section{Rumen Fermentation}

Higher rumen VFA concentrations with pure red clover and a red clover-grass silage diet compared with pure grass silage diets were consistent with previous findings (Bertilsson and Murphy, 2003; Dewhurst et al., 2003a; Vanhatalo et al., 2006). Despite the higher VFA concentration with red clover diets, there were no differences in rumen $\mathrm{pH}$ among forage sources in the present study. A higher concentration of readily fermentable substrates in red clover compared with grass silages and a higher buffering capacity of red clover compared with grass silages may contribute to increased VFA and unchanged $\mathrm{pH}$, respectively. However, the increased molar proportion of acetate in the rumen at the expense of propionate and butyrate with red clover diets compared with grass diets contrasted with the previously reported unchanged rumen fermentation pattern between these plant species (Bertilsson and Murphy, 2003; Dewhurst et al., 2003a; Merry et al., 2006). Differences in the fermentation characteristics of various silages in the silo may partly explain the inconsistent results. In the present study, the lower concentrations of lactic acid and water-soluble carbohydrates (44 vs. 59 and 18 vs. $46 \mathrm{~g} / \mathrm{kg}$ of DM, respectively) in red clover compared with grass silages may be responsible for lower proportions of propionate and butyrate in the rumen of red clover-fed cows. In addition, it may be speculated that the presumed reduced biohydrogenation of long-chain fatty acids in rumen on red clover rather than grass silage diets (Dewhurst et al., 2003b) may have led to a reduced number of protozoa in the rumen and thus contributed to the lower proportion of butyrate in the rumen with red clover diets.

Effects of forage maturity on rumen fermentation pattern were similar for both plant species with decreases in VFA concentrations and a tendency for increases in rumen $\mathrm{pH}$ as well as increases in the molar proportion of acetate and decreases in butyrate with advancing maturity of silages as found previously (Rinne et al., 2002; Harrison et al., 2003).

\section{N Metabolism in the Rumen}

The efficient $\mathrm{N}$ utilization in dairy cow diets stems from meeting, but not exceeding, the $\mathrm{N}$ requirements of rumen microbes and the AA requirements of the host animal (Schwab et al., 2005). The experimental diets were designed to be sufficient in RDP in terms of dietary CP concentration exceeding $13.1 \%$ in DM (Schwab et al., 2005). The average dietary CP concentrations were $14.4,13.0,19.2,17.4$, and $16.2 \%$ for early- and late-cut grass, early- and late-cut red clover, and the mixed forage diet, respectively. Because of the higher CP concentrations, the CP intakes as well as rumen ammonia concentrations were much higher for red clover-fed than for grass silage-fed cows, being in the range of values for pure red clover diets obtained previously (Dewhurst et al., 2003b; Merry et al., 2006; Broderick et al., 2007). However, in relation to high dietary CP concentration of red clover diets, the average rumen ammonia concentrations below $7.5 \mathrm{mmol} / \mathrm{L}$ and the highest peak during the feeding interval below $12.7 \mathrm{mmol} / \mathrm{L}$ obtained for red clover diets may be considered relatively low compared with previous data for grass silage diets (Ahvenjärvi et al., 1999; Rinne et al., 2002). This was consistent with the reduced ruminal N degradability of red clover diets in the present study, as will be discussed later.

On the other hand, the average rumen ammonia values for grass silage diets were clearly lower than found in other studies with similar dietary CP contents (Ahvenjärvi et al., 1999; Korhonen et al., 2002b). Because both grass silages in the present study were well preserved and of high digestibility (digestible OM concentration $>68 \%$ of DM), the low rumen ammonia values for these diets may indicate a potentially efficient microbial protein synthesis in the rumen. Nevertheless, it is unclear if the observed rumen ammonia concentrations $<2 \mathrm{mmol} / \mathrm{L}$ occasionally observed during the feeding interval, irrespective of the grass silage growth stage, as reported in our companion paper (Kuoppala et al., 2009), were sufficiently high to maximize rumen digestion and microbial protein synthesis. Schwab et al. (2005) pointed out that no fixed optimal ruminal ammonia concentration can be defined, but it depends on various dietary factors. They concluded that rumen ammonia- $\mathrm{N}$ concentrations of 5 to $11 \mathrm{mmol} / \mathrm{L}$ are needed to maximize flow of microbial protein from the rumen, but also that concentrations $>5 \mathrm{mmol} / \mathrm{L}$ will result in increased $\mathrm{N}$ losses from the rumen. 
Milk urea concentrations varied from $140 \mathrm{mg} / \mathrm{L}$ for the late-cut grass silage diet to $369 \mathrm{mg} / \mathrm{L}$ for the earlycut red clover diet in the present study. This demonstrates that the lowest value was close to $160 \mathrm{mg} / \mathrm{L}$, which has been suggested to indicate an adequacy of RDP in the diet, and the highest value was $<450 \mathrm{mg} / \mathrm{L}$, which seems to be approximately the upper limit for milk and milk protein yield responses (Nousiainen, 2004). The calculated dietary CP balances in the rumen were only slightly lower than the obtained CP concentrations of the dietary treatments in the present study (Table 4). These estimates suggest that a substantially higher dietary CP concentration for red clover compared with grass silage diets and a slightly higher dietary $\mathrm{CP}$ concentration for early- compared with late-harvested silage diets were needed to satisfy the microbial requirements for rumen-degradable $\mathrm{N}$ in the present study.

Higher total NAN flows entering the lower tract with red clover than with grass silage diets were in agreement with previous results (Dewhurst et al., 2003b; Merry et al., 2006; Vanhatalo et al., 2006). However, the increased total NAN flow with red clover diets was composed mainly of dietary NAN. Thus, contribution of microbial NAN to the total NAN was, on average, lower with red clover $(63 \%)$ than with grass silage diets $(69 \%)$. These findings agree with previous red clover versus grass silage comparisons (Dewhurst et al., 2003b; Merry et al., 2006; Vanhatalo et al., 2006) and are consistent with the results of Brito et al. (2007) on red clover diets. The higher dietary NAN flow with red clover resulted from a reduced $\mathrm{N}$ degradability in the rumen of red clover silage diets (64.3 vs. $69.6 \%$ ) as reported before (Dewhurst et al., 2003a; Merry et al., 2006; Vanhatalo et al., 2006) and has been attributed to PPO activity inherent to red clover (Jones et al., 1995; Lee et al., 2004; Sullivan and Hatfield, 2006). The observation that harvesting at a more mature growth stage decreased microbial NAN flow with grass diets but increased it with red clover diets obviously reflected the corresponding changes in silage DMI. The higher efficiency of microbial protein synthesis in the rumen of animals fed red clover compared with grass diets has been observed in dairy cows (Dewhurst et al., 2003a; Vanhatalo et al., 2006) but not in steers (Merry et al., 2006). The present estimates of improved efficiencies may be attributed to a slightly higher omasal microbial flow and a slightly lower amount of OM digested in the rumen of red clover-fed than grass silage-fed cows.

\section{AA Profile of Postruminal Digesta and Plasma}

Brito et al. (2007) compared red clover versus alfalfa silage diets in terms of individual AA flows at the omasal canal, but there are few, if any, previous data on postruminal AA flows comparing red clover and grass silage diets. In the present study, the higher omasal flows of EAA and NEAA and higher concentrations of EAA and total AA in arterial plasma with red clover compared with grass diets were consistent with the higher NAN flows, suggesting an increased supply of absorbed AA from red clover diets. This was further supported by a higher proportion of EAA in the arterial plasma AA with red clover than with grass diets. However, there were differences in the omasal flows of individual AA such that using red clover silages instead of grass silages increased all the individual AA flows significantly except those of sulfur AA Met and Cys (Table 5). This was further reflected in reduced concentrations of Met and Cys in the AA profile of omasal digesta (Table 6) and reduced concentrations of Met in arterial plasma (Table 7) with red clover silage diets compared with grass silage diets. Furthermore, this together with the numerically higher extraction rate (59.2 vs. $51.1 \%$ ) and the lower uptake of Met (0.62 vs. $0.90 \mathrm{~g} / \mathrm{kg}$ of milk) by the mammary gland on red clover compared with grass diets may offer an explanation for the unchanged milk protein yields between plant species in this and other trials (Dewhurst et al., 2003a). This suggests that an inadequate supply of Met to the mammary gland limited further milk protein synthesis despite the enhanced total AA supply on red clover diets. On the other hand, concentrations of Leu and Phe in the omasal digesta and arterial plasma were lower for grass than red clover silage diets. Because extraction of Leu by the mammary gland ( 43.4 vs. $28.0 \%$ ) was also much higher for grass than red clover diets, it may be speculated that the supply of Leu was inadequate on grass silage-based diets in the present study.

Using empirical infusion studies, His has been identified as the first-limiting AA for milk protein synthesis on grass silage cereal-based diets (Vanhatalo et al., 1999; Korhonen et al., 2000; Kim et al., 2001). Moreover, Leu has been proposed as a second-limiting AA after His (Varvikko et al., 1999; Kim et al., 2001) but attempts to demonstrate that have failed (Huhtanen et al., 2002; Korhonen et al., 2002a). The fact that His was not limiting in the present study is supported by the high arterial plasma His concentrations in all the experimental diets in relation to the previously reported diets with inadequate His supply (Vanhatalo et al., 1999; Korhonen et al., 2000). This may be explained by the use of rapeseed expeller as a protein supplement that is relatively rich in His. Methionine and (or) Lys have often been considered as first-limiting AA in corn-based diets (Schwab et al., 1992) but not on grass silage diets (Vanhatalo et al., 1999; Varvikko et al., 1999). However, the first-limiting AA on grass silage 
cereal-based diets has varied between His and Met in various experiments depending on the composition of the mixture of AA absorbed from the gut (Chamberlain and Yeo, 2003).

The present results suggest that the AA supply of cows fed pure red clover versus grass silage diets with a standard cereal-based concentrate supplement including a moderate amount of rapeseed expeller differ notably from each other. The content of Met in the omasal digesta seems to be low on red clover-based diets and that of Leu on grass silage-based diets. The present omasal Met content in red clover-fed cows of $2.3 \mathrm{~g} / 100 \mathrm{~g}$ of AA was nevertheless higher than that of 1.8 obtained for red clover diets in the study of Brito et al. (2007), the differences between the studies probably arising from the various protein supplements used (rapeseed expeller vs. soybean meal). The present omasal Met content of $2.6 \mathrm{~g} / 100 \mathrm{~g}$ of AA for grass silage diets was consistent with previous findings varying in the range of 2.6 to $2.8 \mathrm{~g} / 100 \mathrm{~g}$ of AA (Korhonen et al., 2000, 2002a,b). Leucine contents of 8.2 and $8.6 \mathrm{~g} / 100 \mathrm{~g}$ of AA for grass and red clover silage diets, respectively, were in agreement with previous results (Korhonen et al., 2000; 2002a,b; Brito et al., 2007). However, despite the low content of Leu in the omasal digesta of the grass silage diet, infusion of Leu into the abomasum in the study of Korhonen et al. (2002a) did not increase milk protein yield.

The possibility of Met being a marginally limiting AA on red clover diets in the present study may be supported by our recent study (A. Vanhatalo; unpublished data) demonstrating that cows fed red clover silage as a sole forage in the diet responded to an increasing amount of rapeseed expeller in the diet by increasing plasma Met and milk protein content. Thus, the reduced Met supply on red clover-based silage diets seems obvious, but the reason for this is unclear. Lee et al. (2008) suggested that the bioavailability of sulfoamino acids in red clover-fed animals may have been affected because of the combined PPO and $o$-diphenol system inherent to red clover (Sullivan and Hatfield, 2006). Our results suggest impaired bioavailability of Met on red clover-based silage diets, this possibly being an explanation for reduced milk protein content on the red clover diets in the present study.

\section{$\mathbf{N}$ Partitioning in Cows}

Although the present estimates of the $\mathrm{N}$ balance varying in range of 45 to $71 \mathrm{~g} / \mathrm{d}$ and equating to about 1.1 to $1.8 \mathrm{~kg} / \mathrm{d}$ of BW gain are far too high to be realistic (Firkins and Reynolds, 2005), it may be appropriate to compare treatment differences within the study. The high estimates and a tendency for higher $\mathrm{N}$ retention with red clover than with grass silage diets were consistent with the previously reported results (Bertilsson and Murphy, 2003; Moorby et al., 2009). Decreased N retention with advancing maturity of forage sources was in line with the results of Broderick et al. (2007) for red clover silage but not with the results of Kebreab et al. (2000) for grass silage diets. A reason for the high $\mathrm{N}$ balance estimates measured in the present and other studies is unclear, but it may be attributed to an attainment of positive body $\mathrm{N}$ status at an earlier stage of lactation than an attainment of positive energy balance (Sutter and Beever, 2000). Previously measured N retention estimates for similar type of grass silage diets in cows at the early or mid stages of lactation ranged from 19 to $40 \mathrm{~g} / \mathrm{d}$ in our laboratory (Ahvenjärvi et al., 2002; Korhonen et al., 2002b).

Because of the much higher $\mathrm{N}$ intake of red clover diets, the total $\mathrm{N}$ excretions of red clover diets were higher than those of grass silage diets. Also, a higher proportion of $\mathrm{N}$ was excreted in urine rather than in feces on red clover-based diets, whereas the opposite was true for grass silage diets. This corresponds well with the calculation that excretion of $\mathrm{N}$ in the urine increases exponentially as soon as $\mathrm{N}$ intake exceeds 400 $\mathrm{g} / \mathrm{d}$ or dietary $\mathrm{CP}$ content exceeds $15 \%$ in diet $\mathrm{DM}$ (Castillo et al., 2000). In terms of environmental pollution, urinary $\mathrm{N}$ is considered to have greater impact than fecal N. Therefore, nutritional strategies such as using starch rather than fiber-based concentrates to shift $\mathrm{N}$ excretion from urine to feces have been recommended (Kebreab et al., 2000). The efficiency of dietary $\mathrm{N}$ conversion into milk $\mathrm{N}$ of $23 \%$ for pure red clover diets agrees with other studies (Bertilsson and Murphy, 2003; Dewhurst et al., 2003b; Broderick et al., 2007) and was relatively low compared with $29 \%$ for grass silage diets in the present study. However, the feed $\mathrm{N}$ efficiency of the control grass silages used in the various studies (Bertilsson and Murphy, 2003; Dewhurst et al., 2003b; Moorby et al., 2009) varied in the range of 22 to $26 \%$ with the $\mathrm{CP}$ content of the silages varying from 13.9 to $20.6 \%$ in DM. A low feed $\mathrm{N}$ efficiency on the mixed forage diet (24\%) was because of higher silage DMI on this particular diet compared with the sole grass or red clover diets. Overall, this demonstrates that the $\mathrm{CP}$ content of the silage is not the only determinant of feed $\mathrm{N}$ efficiency. It should be noted that only a moderate level of standard concentrate was used in the present (38\% in diet DM) and other studies (Bertilsson and Murphy, 2003; Dewhurst et al., 2003b; Moorby et al., 2009). An efficient nutritional strategy for carbohydrate and protein supplementation of red clover-based diets to improve dietary $\mathrm{N}$ conversion into milk N should be developed. Possibilities for reducing the dietary $\mathrm{CP}$ content of red clover diets by using 
rumen-protected AA warrants further study. Growing red clover with grasses also results in decreased dietary $\mathrm{CP}$ concentrations. Improved nutritional strategies would enable increasing utilization of atmospheric $\mathrm{N}$ in terms of using legumes such as red clover in dairy cow forage production.

\section{CONCLUSIONS}

Replacing grass silage with red clover silage resulted in increased $\mathrm{N}$ intakes and ammonia $\mathrm{N}$ concentrations in the rumen fluid but also reduced ruminal $\mathrm{N}$ degradability. Rumen fermentation pattern of red clover versus grass diets was characterized by higher molar proportions of acetate and lower molar proportions of propionate and butyrate, the forage maturity effects being similar for both forage sources. Differences in rumen fermentation contributed to reduced milk fat contents on red clover versus grass diets. Use of red clover rather than grass silage diets led to higher efficiency of microbial protein synthesis in the rumen, and increased omasal flows of total NAN composed mainly of increased dietary NAN. Omasal canal AA flows and omasal canal AA as well as plasma AA concentrations, except for lowered Met, were generally much higher for red clover than for grass silage diets, but they were not affected by the stage of maturity of the forages. Despite the higher AA supply on red clover than grass diets, further production responses, especially in terms of milk protein content, were probably limited by an inadequate supply of Met in the diet.

\section{ACKNOWLEDGMENTS}

The authors thank staff of the experimental unit led by Laila Hakkarainen for care of experimental animals, and laboratory staff led by Vesa Toivonen for chemical analyses of the samples, both at MTT Agrifood Research Finland in Jokioinen. This work was financially supported by the Finnish Ministry of Agriculture and Forestry.

\section{REFERENCES}

Ahvenjärvi, S., A. Vanhatalo, and P. Huhtanen. 1999. Effects of supplementation of a grass silage and barley diet with urea rapeseed meal and heat-moisture-treated rapeseed cake on omasal digesta flow and milk production in lactating dairy cows. Acta Agric. Scand. A Anim.Sci 49:179-189.

Ahvenjärvi, S., A. Vanhatalo, and P. Huhtanen. 2002. Supplementing barley or rapeseed meal to dairy cows fed grass-red clover silage: I. Rumen degradability and microbial flow. J. Anim. Sci. 80:21762187.

Ahvenjärvi, S., A. Vanhatalo, P. Huhtanen, and T. Varvikko. 2000. Determination of reticulo-rumen and whole stomach digestion in lactating cows by omasal canal and duodenal sampling. Br. J. Nutr. 83:67-77.
Albrecht, K. A., and K. Beauchemin. 2003. Alfalfa and other perennial legume silage. Pages 633-664 in Silage Science and Technology. D. Buxton, R. Muck, and J. Harrison, ed. Agronomy 42. American Society of Agronomy, Crop Science Society of America, and Soil Science Society of America, Madison, WI.

Bertilsson, J., and M. Murphy. 2003. Effects of feeding clover silages on feed intake, milk production and digestion in dairy cows. Grass Forage Sci. 58:309-322.

Binnerts, W. T., A. Th. van't Klooster, and A. M. Frens. 1968. Soluble chromium indicator measured by atomic absorption in digestion experiments. Vet. Rec. 82:470.

Brito, A. F., G. A. Broderick, J. J. Olmos Colmenero, and S. M. Reynal. 2007. Effects of feeding formate-treated alfalfa silage or red clover silage on omasal nutrient flow and microbial protein synthesis in lactating dairy cows. J. Dairy Sci. 90:1392-1404.

Broderick, G. A., A. F. Brito, and J. J. Olmos Colmenero. 2007. Effects of feeding formate-treated alfalfa silage or red clover silage on the production of lactating dairy cows. J. Dairy Sci. 90:1378-1391.

Castillo, A. R., E. Kebreab, D. E. Beever, and J. France. 2000. A review of efficiency of nitrogen utilisation in lactating dairy cows and its relationship with environmental pollution. J. Anim. Feed Sci. $9: 1-32$

Chamberlain, D. G., and J.-M. Yeo. 2003. Effects of amino acids on milk production. Pages 369-387 in Amino Acids in Animal Nutrition. J. P. F. D'Mello, ed. Biddles Ltd., Guildford and King's Lynn, UK.

Dewhurst, R. J., R. T. Evans, N. D. Scollan, J. M. Moorby, R. J. Merry, and R. J. Wilkins. 2003a. Comparison of grass and legume silages for milk production. 2 . In vivo and in sacco evaluations of rumen function. J. Dairy Sci. 86:2612-2621.

Dewhurst, R. J., W. J. Fisher, J. K. S. Tweed, and R. J. Wilkins 2003b. Comparison of grass and legume silages for milk production. 1. Production response with different levels of concentrate. J. Dairy Sci. 86:2598-2611.

Firkins, J. L., and C. Reynolds. 2005. Whole-animal nitrogen balance in cattle. Nitrogen requirements of cattle. Pages 167-186 in Nitrogen and Phosphorus Nutrition of Cattle. Reducing the Environmental Impact of Cattle Operations. E. Pfeffer, and A. Hristov, ed. Biddles Ltd., King's Lynn, UK.

France, J., and R. C. Siddons. 1986. Determination of digesta flow by continuous marker infusion. J. Theor. Biol. 121:105-119.

Harrison, J., P. Huhtanen, and M. Collins. 2003. Perennial grasses. Pages 635-747 in Silage Science and Technology. D. R. Buxton, R. E. Muck, and J. H. Harrison, ed. American Society of Agronomy, Crop Science Society of America, and Soil Science Society of America, Madison, WI.

Heikkilä, T., V. Toivonen, and T. Mela. 1996. Effects of red clover-grass, grass and annual ryegrass silages with two concentrate protein levels on milk production. Grassland and Land Use Systems. Pages 447-450 in Proc. 16th General Mtg. Eur. Grassl. Fed., Grado (Gorizia), Italy. G. Parente, J. Frame and S. Orsi, ed. ERSA, Ente Regionale per la Promozione e lo Sviluppo dell'Agricolture Via Montesanto, Italy.

Huhtanen, P., M. Rinne, and J. Nousiainen. 2007. Evaluation of the factors affecting silage intake of dairy cows: A revision of the relative silage dry-matter intake index. Animal 1:758-770.

Huhtanen, P., A. Vanhatalo, and T. Varvikko. 2002. Effects of abomasal infusions of histidine, glucose and leucine on milk production and plasma metabolites of dairy cows fed grass silage diets. J. Dairy Sci. 85:204-216.

Jaakkola, S., V. Kaunisto, and P. Huhtanen. 2006. Volatile fatty acid proportions and microbial protein synthesis in the rumen of cattle receiving grass silage ensiled with different rates of formic acid. Grass Forage Sci. 61:282-292.

Jones, B. A., R. E. Muck, and R. D. Hatfield. 1995. Red clover extracts inhibit legume proteolysis. J. Sci. Food Agric. 67:329-333.

Kebreab, E., A. R. Castillo, D. E. Beever, D. J. Humphries, and J. France. 2000. Effects of management practices prior to and during ensiling and concentrate type on nitrogen utilization in dairy cows. J. Dairy Sci. 83:1274-1285. 
Kim, C.-H., J.-J. Choung, and D. G. Chamberlain. 2001. Responses of milk production to the intra-venous infusion of amino acids in dairy cows given diets of grass silage and cereal-based supplements. J. Anim. Phys. Anim. Nutr. 85:293-300.

Korhonen, M., A. Vanhatalo, and P. Huhtanen. 2002a. Evaluation of isoleucine, leucine, and valine as a second-limiting amino acid for milk production in dairy cows fed grass silage diet. J. Dairy Sci. $85: 1533-1545$.

Korhonen, M., A. Vanhatalo, and P. Huhtanen. 2002b. Effect of protein source on amino acid supply, milk production, and metabolism of plasma nutrients in dairy cows fed grass silage. J. Dairy Sci. 85:3336-3351.

Korhonen, M., A. Vanhatalo, T. Varvikko, and P. Huhtanen. 2000. Lactation and metabolic responses to graded postruminal doses of histidine in cows fed grass silage diets. J. Dairy Sci. 83:25962608.

Kuoppala, K., S. Ahvenjärvi, M. Rinne, and A. Vanhatalo. 2009. Effects of feeding grass or red clover silage cut at two maturity stages in dairy cows. 2. Dry matter intake and cell wall digestion kinetics. J. Dairy Sci. 92:5634-5644.

Lee, M. R. F., J. K. S. Tweed, N. D. Scollan, and M. L. Sullivan. 2008. Ruminal micro-organisms do not adapt to increase utilization of poly-phenol oxidase protected red clover protein and glycerolbased lipid. J. Sci. Food Agric. 88:2479-2485.

Lee, M. R. F., A. L. Winters, N. D. Scollan, R. J. Dewhurst, M. K. Theodorou, and F. R. Minchin. 2004. Plant-mediated lipolysis and proteolysis in red clover with different polyphenol oxidase activities. J. Sci. Food Agric. 84:1639-1645.

Merry, R. J., M. R. F. Lee, D. R. Davies, R. J. Dewhurst, J. M. Moorby, N. D. Scollan, and M. K. Theodorou. 2006. Effects of high-sugar ryegrass silage and mixtures with red clover silage on ruminant digestion. 1 . In vitro and in vivo studies on nitrogen utilization. J. Anim. Sci. 84:3049-3060.

Moorby, J. M., M. R. F. Lee, D. R. Davies, E. J. Kim, G. R. Nute, N. M. Ellis, and N. D. Scollan. 2009. Assessment of dietary ratios of red clover and grass silages on milk production and milk quality in dairy cows. J. Dairy Sci. 92:1148-1160.

MTT. 2006. Rehutaulukot ja ruokintasuositukset (Feed tables and feeding recommendations). MTT Agrifood Research Finland, Jokioinen. http://www.mtt.fi/rehutaulukot/ Accessed Feb. 19, 2009 .

Nousiainen, J. 2004. Development of tools for the nutritional management of dairy cows on silage-based diets. $\mathrm{PhD}$ thesis. University of Helsinki, Finland. Department of Animal Science Publications 72. http://ethesis.helsinki.fi/julkaisut/maa/kotie/ vk/nousiainen/ Accessed Feb. 20, 2009.
Rinne, M. 2000. Influence of the timing of the harvest of primary grass growth on herbage quality and subsequent digestion and performance in the ruminant animal. $\mathrm{PhD}$ thesis. University of Helsinki, Finland. Department of Animal Science Publications 54 http://ethesis.helsinki.fi/julkaisut/maa/kotie/vk/rinne. Accessed Feb. 20, 2009.

Rinne, M., P. Huhtanen, and S. Jaakkola. 2002. Digestive processes of dairy cows fed silages harvested at four stages of grass maturity J. Anim. Sci. 80:1986-1998.

Schwab, C. G., C. K. Bozak, N. L. Whitehouse, and V. M. Olsen. 1992. Amino acid limitation and flow to the duodenum at four stages of lactation. 2. Extent of lysine limitation. J. Dairy Sci. 75:3503-3518

Schwab, C. G., P. Huhtanen, C. W. Hunt, and T. Hvelplund. T. 2005. Nitrogen requirements of cattle. Pages 13-70 in Nitrogen and Phosphorus Nutrition of Cattle. Reducing the Environmental Impact of Cattle Operations. E. Pfeffer, and A. Hristov, ed. Biddles Ltd., King's Lynn, UK.

Sullivan, M. L., and R. D. Hatfield. 2006. Polyphenol oxidase and o-diphenols inhibit postharvest proteolysis in red clover and alfalfa. Crop Sci. 46:662-670.

Sutter, F. D., and D. E. Beever. 2000. Energy and nitrogen metabolism in Holstein-Friesian cows during early lactation. Anim. Sci. 70:503-514.

Tuori, M., L. Syrjälä-Qvist, and S. Jansson. 2002. Red clover and meadow fescue silages fed in different proportions in milk production. Pages 130-131 in Proc. XIIIth Int. Silage Conf., Auchincruive, Scotland. L. Gechie, and C. Thomas, ed Scottish Agricultural College, Auchincruive, Scotland.

Vanhatalo, A., T. Gäddnäs, and T. Heikkilä. 2006. Microbial protein synthesis, digestion and lactation responses of cows to grass or grass-red clover silage diet supplemented with barley or oats. Agric. Food Sci. 15:252-267.

Vanhatalo, A., P. Huhtanen, V. Toivonen, and T. Varvikko. 1999. Response of dairy cows fed grass silage diets to abomasal infusions of histidine alone or in combinations with methionine and lysine. J. Dairy Sci. 82:2674-2685.

Vanhatalo, A., K. Kuoppala, V. Toivonen, and K. J. Shingfield. 2007. Effects of forage species and stage of maturity on bovine milk fatty acid composition. Eur. J. Lipid Sci. Technol. 109:856-867.

Varvikko, T., A. Vanhatalo, T. Jalava, and P. Huhtanen. 1999 Lactation and metabolic responses to graded abomasal doses of methionine and lysine in cows fed grass silage diets. J. Dairy Sci. 82:2659-2673. 